\title{
$[8]$
}

\section{Retrospect: On Historical Change}

All mankind is of one author, and is one volume; when one man dies, one chapter is not torn out of the book, but translated into a better language; and every chapter must be so translated. God employs several translators; some pieces are translated by age, some by sickness, some by war, some by justice; but God's hand is in every translation, and his hand shall bind up all our scattered leaves again for that library where every book shall lie open to one another.

John Donne, Devotions

I have been considering the extent to which the idea of the Book in the middle ages consists not simply of a definitive content, but rather of specific ways of signifying, organizing, and remembering. It assumes the stability and totalization of knowledge, the belief that all learning can be contained, and the view that history is integral with nature. The metaphor of the Text was inevitably substituted for Building, Body, and Presence; predictable, too, within this tradition was the approach to the Babel story as a destruction of the building of language that was, first of all, deserved (because of self-aggrandizement) but that could nevertheless be rebuilt in the chaste pursuit of a restored discourse-the "proper" reading of the Bible, the creation of a new aedificium Scripturae. This view of language gained such prominence that even the challenges posed by grammar and hermeneutics were ultimately subsumed within more abiding, originary structures. Linguistic theory in the middle ages illustrates what has been called quite suggestively the "dominance of a discourse," that state of language in which analysis and reference can no longer prevail in calling into question their own conditions of signifying and thus cannot establish the grounds for discourse to move in new directions.'

'See Timothy J. Reiss, The Discourse of Modernism (Ithaca: Cornell University

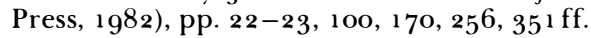


The effect of such stabilization is that skepticism and doubt are suppressed within the larger interests of continuity. The circle of human knowing is maintained, along with the insistence on the geocentric cosmos, the microcosm of man, and the musica tuning nature in perfect harmony. To speak, as I have, of these habits of thought as "mythologizing" is no more than to suggest that their basic elements are not at all new but were well recognized in cultures predating the Christian middle ages. The animism of nature, the interpenetration of divine and human orders, the replication of the transcendent on the model of known and familiar things, the sacralization of stone and volume, and the persistence of megalithism - these forms survive in the middle ages only as vestiges. But what was not displaced was the larger "episteme" (to apply the term of Michel Foucault) in which they functioned - the taxonomic patterning of all cultural forms. ${ }^{2}$ The metaphor of the Book or Text that has been used to characterize such a cultural episteme takes on quite literal proportions in the medieval centuries, as knowledge was collected and stored in great books or as the transcendental world was replicated in the sacred space of religious architecture. Although the mythology of the Book reaches back to precedent centuries, scholarship on historical change in the middle ages has commonly begun with a different assumption, one that was made by medieval thinkers themselves and that carries out their attempt to displace the past by creating something entirely new. Indeed, they did create new objects of knowledge, but the ways of knowing remained rooted in past habits of thought. In a most basic sense, evolving medieval cultural forms need to be examined much more closely for the archaic mythology still present in them.

But I have also been suggesting that the grounds of signifying meaning in the middle ages were shifting in another domain - the fictionalizing discourse of the poets. Literary language posed - as Plato always feared it would - a challenge to the cultural utopia. Augustine shared Plato's fear about literature, distrusting it not simply because it was pagan, but because it was literature. Its pleasures threatened the rules of proper response, raising the potential for doubt and risking the possibility of completely arbitrary conclusions. A perspective sub specie aeternitatis, such as Augustine assumes for himself in the Confessions, could no longer be guaranteed to control meaning in a discourse conceiving of boundaries as fic-

${ }^{2}$ Michel Foucault, The Order of Things: An Archaeology of the Human Sciences (New York: Pantheon, 1971), chap. 2, "The Prose of the World," esp. section 3. 
tive. Even at this early stage in the literary theory of the Western tradition, Augustine intuits in his distrust of literature the fictivity of the so-called reliable narrator. No narrators are ultimately reliable in fictional texts, and that is one reason fiction departs from myth, the books of the poets from the ideal Book of culture. If myths have no authors and exist as the given structures within which a society lives, fictions arise from the much more limited, contingent vantage of a specific writer. Although a poet's ambition may be, as was Dante's, to copy the architecture of his universe and mirror the auctoritas of the past, his language, in carrying out that project, sets in motion a critique that undermines its foundation. His poem is about the dream of the medieval Book to fulfill itself and illuminate the dark secrets in the house of intellect; but like all fictions, it remains bound within the laws and limits of its own order of designating. In this way, the Commedia opposes the myth of the Book, which never gives up the fantasy of containing all within its sacred confines. That pursuit is powerfully sanctioned by the institution of interpreting presided over by the medieval church, whose apologists compared their proprieties of reading to the preservation of ecclesiastical chastity: only with "circumcised lips" and "tongue" will Augustine approach the "chaste delights" of the sacra pagina. ${ }^{3}$ But Dante, however much he is indebted to the idea of the Book in Augustine's Confessions, creates a discourse that is separate from it.

The structure of this separation or departure, as I have called it, is hardly as simple as the end of one episteme and the beginning, ex nihilo, of another that is entirely new. It may be compared, instead, to the shift from oral to written discourse that was taking place at various points in time during the middle ages, including Dante's own. As this shift has been studied recently and compellingly, it may be recognized as a departure from the certainty of meaning present in the spoken word to the less certain and often ambiguous implications of the written. ${ }^{4}$ The need for textual communities arises in order to appeal to a consensus regarding the meaning of texts and to put back the authority that is loosened when oral communication is displaced by print: the potential for indeterminacy that is on the horizon of textual signification may thereby be ruled safely out of bounds. This shift from speaking to

${ }^{3}$ Augustine, Confessions $11.2(P L$ 32, 809-810).

${ }^{4}$ See Brian Stock, The Implications of Literacy: Written Language and Models of Interpretation in the Eleventh and Twelf th Centuries (Princeton: Princeton University Press, 1983). 
writing may be further understood as a historical instance of the Saussurian separation of langue from parole: the metalanguage of Latin, its grammar and the logical structures that control the study of it, are distinguished from real instances of speaking and writing not only in Latin but even more emphatically in the vernacular languages as well. ${ }^{5}$ Yet since neither of these separations is as sharp as it may appear, certainly not as clear-cut as Saussure himself imagined, they do not shed quite enough light on the nature of historical change that is catalyzed by the textuality of poetic language in the Commedia. For if Saussure's distinction remains finally a structure of "différence," as Derrida has argued, in which written or spoken utterance is a "marginal supplement" of the systematic langue to which it belongs, then the discourse of the Commedia establishes a ground of signification that is very different from the architectonic Text from which it derives, such as the one figured in light at the end of the Paradiso. ${ }^{6}$ The glossamatics of that celestial Book remain committed to fixing and stabilizing the meaning of what is written, since the marginal commentary is imagined as a simple addition to a source that is already complete, like the dazzling illuminations of late medieval manuscripts. But insofar as Dante's poem is marginal with respect to its origin in the Book of memory, it names the incompleteness of what it supplements at the same time as it demonstrates its own inability to be complete. Its supplementary relationship to the artifice of form is no longer mystified by the assumption of complete illumination: Dante is Argus at the bottom of the infernal ocean of his quest even as he approaches the source of paradisal light in the celestial liber of God. That Text is the source of fascination precisely because it is the vision of perfect and definite signification; but Dante's poetic language recognizes and unveils its own limits, thereby unsettling the stability of meaning. How language signifies determines what may in fact be understood.

Medieval grammarians, especially the modistae, appreciated this linguistic function more deeply than most students of writing, and yet the object of language prevailed over its mode in the development of their disciplines. As linguistics remained determined by semantics, so too Scholastic logic and dialectic, although they expanded speculative grammar widely, were projected in the processes of describing linguistic phenomena per se: philosophical

${ }^{5}$ Ibid., pp. $88 \mathrm{ff}$., $5^{28}$.

${ }^{6}$ See Derrida's discussion of Saussure and supplementarity in De la grammatologie (Paris: Seuil, 1967); also relevant is his L'Ecriture et la différence (Paris: Seuil, 1967). 
categories were interchangeable with grammatical ones, and signification, in nuce, maintained its stability against the challenge of a metalinguistic analysis. A similar development is traceable in the semiology of spatial forms: as the sign is employed in the process of manifestatio, by which the relationship of signifier and signified is explained, the clarifying process illuminates its own signifying strategies and projects them as the objects of knowledge: the interpretandum remains an interpretans, as nature and history are conceived in terms of hermeneutic principles.

But the conditions of signifying change radically in the hands of the poets. For them fictional writing suspends the priority of meaning, since form asserts itself without hesitation as an object of meaning in its own right. This shift constitutes a departure in the history of signification in the middle ages that is more decisive and consequential than any corresponding movement in the disciplines of grammar and hermeneutics. New capacities for reference become possible once the structures of fixing meaning in the tradition of the Book have been suspended. It has been customary to document the unbinding of the medieval Text many centuries after Dante, in the renaissance and the seventeenth century. We see it, for instance, in John Donne's Devotions (Meditation 17 quoted above), as the feeling of loss in the face of death and its suggestion of the absence of all coherence in the macrocosm are compared to the scattered chapters and leaves of a book that will eventually be rebound by God. ${ }^{7}$ Although typical of Donne and the spirit of an age that was witnessing the breaking up of the Ptolemaic universe, the passage carries out a play with signification that had already been in motion for centuries, and we hear it in the echoes of the conventional imagery of the Book that appears in Chaucer, Dante, and many other sources, including the last book of the Bible. The metaphor fixed by Ambrose and Augustine has been loosened, and the shift in signification may be noted long before Donne in the fictional writing of the middle ages. The boundary line separat-

${ }^{7}$ John Donne, Devotions upon Emergent Occasions, in Seventeenth-Century Prose and Poetry, ed. Alexander M. Witherspoon and Frank J. Warnke, 2d ed. (New York: Harcourt, Brace \& World, 1963), p. 68. A much more pessimistic note on this subject is sounded by Donne in The First Anniversary: An Anatomy of the World. Related to the cosmological revolution, see for example Marjorie H. Nicolson, The Breaking of the Circle: Studies in the Effect of the "New Science" on Seventeenth-Century Poetry, rev. ed. (New York: Columbia University Press, 1960), and John Hollander, The Untuning of the Sky: Ideas of Music in English Poetry, $1500-1700$ (Princeton: Princeton University Press, 1961). 
ing the historical "period" of the "Middle Ages" from the "Renaissance" - the revolution of an new episteme - should therefore be recognized as a far more subtle and qualified change. ${ }^{8}$

Insofar as this shift illustrates the function of linguistic phenomena, its structure is motivated not by the causality of Scholastic logic, but by the supplementary logic of differentiating discourse. If this way of reflecting on historical change adjusts the apparently mechanical and abrupt notion of an epistemic break, it also suggests that the ahistorical or transhistorical character of deconstruction cannot avoid confronting the facts of its own history in the medieval opposition of poetic textuality to the myth of the Text. Certainly many writers before the seventeenth century felt the grounds of signification shifting beneath them: Augustine saw the potential for arbitrary response when he meditated on language as a model for the temporality of the fallen world; Aquinas acknowledged an abiding separation between the transcendent reference of learning and the linguistic modus quo. But in both writers a discourse of analysis and reference is forestalled from radical departures because the governing structure within which they worked is never unsettled. In Dante, however, that structure is pointedly questioned as soon as language accepts the factors of its own impossibility, and in Chaucer this situation is before us even more provocatively. A reflection on his work invites a reconsideration of the "origins" of deconstruction as well as the unavoidable historicism it implies.

Writing about Chaucer may begin, at least provisionally, with the recognition that the sentence-despite its medieval popularity as a meditation on time - is not the model for narrative in his poetry, and that in turn narrative is not the matrix from which the larger text takes its structure. This claim, of course, does not imply that the only adequate criticism, for example, of The Knight's Tale is another poem, like the Miller's, or that the best critique of The Canterbury Tales as a whole is The Nun's Priest's Tale - though every reader of Chaucer suspects how perfectly appropriate such "criticism" is. My point is, rather, that models of closure (the sentence) or se-

${ }^{8}$ Foucault, in Order of Things (pp. 50-77) assumes this kind of sharp split between the "Classical episteme" and the seventeenth century. Reiss, in Discourse of Modernism, argues for a more qualified sense of historical transition in his concept of "analytico-referential discourse"; but he would situate the consolidation of this discourse between approximately $15^{\circ 0}$ and $165^{\circ}$, whereas I suggest it is a factor of fictional writing going back to the poets of the middle ages. 
quentiality (narrative) are not quite adequate insofar as they invite conceiving of meaning as something that is complete and stable in a text. Such a conception-because it was so conventional-found its way obviously into Chaucer's poetry; but it appears, in The House of Fame, as a "fantasye," the timelessness of a mythological dream that is constantly submitted to the time-bound qualifications of the dreamer's understanding and the contingencies of what language can represent. The dream as a structure for the text undergoes the same criticism as the "naked text" in the "Prologue" to The Legend of Good Women: in itself such a figure of meaning is less interesting than the elusive dress of possible readings. The ornamentality of language in Chaucer's early poetry takes priority as a reflection on textuality because it occasions the recognition of the temporal limits of interpreting.

Regarding the later poetry, The Canterbury Tales, various models of the Book have been proposed as principles of structure. But each of them - the Bible, sacred architecture, and memory - rests on a premise of aesthetic imitation, whereas the properties of poetic language seem far more interested in interpreting their own rhetorical mode as well as inherited models of the Text. Literary structure (the word is finally limited by its roots in concrete things) is a process arising in response to the inevitable gaps and uncertainties of utterance. Rather than apologizing for such qualities of discourse or mystifying them with concealed, secret meaning, Chaucer's texts acknowledge them for what they are and grant the reader the authority to complete the circle of understanding. Nowhere is this self-disclosure of textuality more direct than in the confused conclusions drawn by the narrator in the "General Prologue"; but it is obvious, too, in other places, such as the remarks of the Wife of Bath and even those of the Parson, who closes the Tales. $\mathrm{He}$, for example, asks us to reflect with him on some final matters, as we are "entering at a thropes ende" ("Pars. Prol.," 13); he refers to the outskirts of a town, but the text is inviting us to contemplate the "entering" or "beginning" now that the "thropes ende" is leading to the final "trope"-the pilgrimage as a quest to the City of God, "That highte Jerusalem Celestial" ("Pars. Prol.," $5^{1}$ ). It is yet another image of the text as divine object, the sacred city; but it is also, contrary to the Parson's own expression, not the terminus ad quem of his discourse. Instead, his remarks before closing are the occasion for entering into questions that his discourse may have left incomplete, for he would not want to have the last word, in all humility; and so he says: 


\section{Retrospect: On Historical Change}

I put it ay under correccioun

Of clerkes, for I am not textuel.

("Pars. Prol.," 56-57)

Only the learned should have the right to pass judgment on what he has said. How utterly respectful of auctores. But his own utterance is passing judgment, too, as it appeals to an authority in itself that it is disclaiming. Speaking thus "under correccioun" is not only the Parson's style; it is also the modus significandi of The Canterbury Tales as well as the way linguistic phenomena behave generally in medieval fictional writing. Meditations on this body of literature take us back to the evidence of deconstruction that was under way many years before the "discovery" of the movement in the twentieth century, and to the recognition that poetic language in any time may offer similar evidence for writing about the relation of literature to culture. Medieval poetry has no particular privilege in this endeavor. But it does illustrate exceptionally well that historical factors are deeply embedded in language and, therefore, that efforts to separate them through critical commentary on fictional writing will bring us closer to what happened in history. Linguistic factors claim our attention first, if only because we, like the poets, assess the past primarily through language. 
